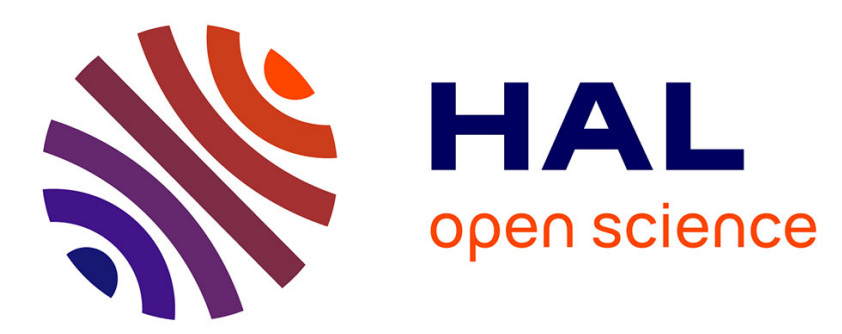

\title{
Past and future changes in biogenic volatile organic compound emissions simulated with a global dynamic vegetation model
}

Juliette Lathiere, Didier Hauglustaine, Nathalie de Noblet-Ducoudré, Gerhard Krinner, G. A. Folberth

\section{To cite this version:}

Juliette Lathiere, Didier Hauglustaine, Nathalie de Noblet-Ducoudré, Gerhard Krinner, G. A. Folberth. Past and future changes in biogenic volatile organic compound emissions simulated with a global dynamic vegetation model. Geophysical Research Letters, 2005, 32 (L20818), 1 à 4 p. 10.1029/2005GL024164 . insu-00374612

\section{HAL Id: insu-00374612 \\ https://hal-insu.archives-ouvertes.fr/insu-00374612}

Submitted on 1 Mar 2021

HAL is a multi-disciplinary open access archive for the deposit and dissemination of scientific research documents, whether they are published or not. The documents may come from teaching and research institutions in France or abroad, or from public or private research centers.
L'archive ouverte pluridisciplinaire HAL, est destinée au dépôt et à la diffusion de documents scientifiques de niveau recherche, publiés ou non, émanant des établissements d'enseignement et de recherche français ou étrangers, des laboratoires publics ou privés. 


\title{
Past and future changes in biogenic volatile organic compound emissions simulated with a global dynamic vegetation model
}

\author{
J. Lathière, D. A. Hauglustaine, and N. De Noblet-Ducoudré \\ Laboratoire des Sciences du Climat et de 1'Environnement (LSCE), Gif-sur-Yvette, France \\ G. Krinner \\ Laboratoire de Glaciologie et Géophysique de l'Environnement (LGGE), Saint Martin d'Heres, France \\ G. A. Folberth \\ School of Earth and Ocean Sciences (SEOS), University of Victoria, Victoria, British Columbia, Canada \\ Received 22 July 2005; revised 1 September 2005; accepted 12 September 2005; published 29 October 2005.
}

[1] Based on an interactive global biogenic emission and dynamic vegetation model, we investigate the evolution of volatile organic compound (VOC) emissions by the terrestrial biosphere in four scenarios: the Last Glacial Maximum (21,000 years BP), the preindustrial (1850s), present-day (1990s) and the future (2100). The combined effects of foliar expansion, climate change and ecosystems redistribution impact strongly on biogenic emissions. Total biogenic $\mathrm{VOC}$ emissions increase from $331 \mathrm{TgC} / \mathrm{yr}$ at the LGM to $702 \mathrm{TgC} / \mathrm{yr}$ at the preindustrial, $725 \mathrm{TgC} / \mathrm{yr}$ at present-day and to $1251 \mathrm{TgC} / \mathrm{yr}$ under future conditions. If the tropics remain a major source region, a substantial decrease in VOC emissions is calculated over Amazonia for 2100 due to the recession of tropical forests in response to climate change. The Northern Hemisphere becomes a significant source of VOC in the future and globally, emissions increase by $27 \%$ for isoprene and $51 \%$ for monoterpenes compared to the present. Citation: Lathière, J., D. A. Hauglustaine, N. De Noblet-Ducoudré, G. Krinner, and G. A. Folberth (2005), Past and future changes in biogenic volatile organic compound emissions simulated with a global dynamic vegetation model, Geophys. Res. Lett., 32, L20818, doi:10.1029/ 2005 GL024164.

\section{Introduction}

[2] The terrestrial biosphere plays a key role in tropospheric chemistry. Isoprene and monoterpenes dominate biogenic VOC emissions, but other reactive chemical species, such as methanol, are also emitted at significant levels [Schade and Goldstein, 2001], yielding an estimated global source of $1150 \mathrm{TgC} / \mathrm{yr}$ [Guenther et al., 1995]. Biogenic VOCs can influence the ozone formation, depending on the NOx levels [Thunis and Cuvelier, 2000]. The oxidation of these VOCs is considered to be a significant source of secondary organic aerosols, with an estimated source strength between 2.5 and $44.5 \mathrm{Tg}$ of organic matter per year for the present day [Tsigaridis and Kanakidou, 2003].

[3] Temperature, radiation, vegetation type and foliar biomass govern biogenic emissions which are thus liable to be very sensitive to climate and vegetation distribution

Copyright 2005 by the American Geophysical Union. 0094-8276/05/2005GL024164 change. Sanderson et al. [2003] calculated an isoprene emission increase from $484 \mathrm{TgC} / \mathrm{yr}$ in the 1990s to 649 $\mathrm{TgC} / \mathrm{yr}$ in the 2090s, in response to climate change, and to $615 \mathrm{TgC} / \mathrm{yr}$ as a consequence of both climate and vegetation distribution changes. Constable et al. [1999] studied variations of biogenic VOC emissions in the USA in response to climate change, and showed that the positive effect of foliar biomass increase in response to elevated $\mathrm{CO}_{2}$ is balanced by the negative effect of ecosystem adjustment to climate change, such as a decrease in the coverage of high VOC emitters.

[4] The purpose of our study is to investigate the evolution of biogenic VOC emissions in four scenarios: the Last Glacial Maximum (21,000 years BP), the preindustrial (1850s), present-day (1990s) and the future (2100). In Section 2, we briefly describe the interactive biogenic emission and vegetation model as well as details of the simulations. In Section 3, the results are presented with a particular emphasis on the evolution of global ecosystems distributions and resulting changes in biogenic VOC emissions. The conclusion is given in Section 4.

\section{Model and Scenario Descriptions}

[5] A biogenic emission scheme, based on Guenther et al. [1995] parameterizations, has been incorporated in the global dynamic vegetation model ORCHIDEE (Organizing Carbon and Hydrology in Dynamic EcosystEms) [Krinner et al., 2005] to estimate isoprene, monoterpenes, methanol, acetone, acetaldehyde, formaldehyde, formic and acetic acids emissions by the terrestrial biosphere [Lathière et al., 2005]. These biogenic VOC emissions depend on temperature, radiation (isoprene) and leaf area index (LAI), and are also conditioned by leaf age (isoprene and methanol) and vegetation type. The distribution of the twelve plant functional types (PFTs) and bare soil, which describe the land-surface, can either be forced using a vegetation map (static mode) or calculated on-line by ORCHIDEE (dynamic mode), depending on climate conditions.

[6] We conducted four simulations: the Last Glacial Maximum (LGM, 21,000 years BP), the preindustrial (1850s), present-day (1990s) and the future (2100). The model is run with a horizontal resolution of $2^{\circ} \times 2^{\circ}$ and forced by reconstructed high frequency $(30 \mathrm{~min})$ meteorological data. 
Table 1. Biogenic VOC Emissions (TgC/yr) Calculated by ORCHIDEE for the Preindustrial and Present-Day With Static Vegetation Distribution, and for the LGM, Present-Day and Future With Dynamic Vegetation ${ }^{\mathrm{a}}$

\begin{tabular}{lcccccc}
\hline & \multicolumn{2}{c}{ Static mode } & & \multicolumn{3}{c}{ Dynamic mode } \\
\cline { 2 - 3 } \cline { 6 - 7 } & Preindustrial & Present & & LGM & Present & Future \\
\hline Isoprene & $409(+2)$ & 402 & & $226(-55)$ & 502 & $638(+27)$ \\
Monoterpenes & $127(-3)$ & 131 & & $49(-72)$ & 175 & $265(+51)$ \\
Methanol & $91(-22)$ & 116 & & $27(-79)$ & 132 & $192(+45)$ \\
Acetone & $46(-2)$ & 47 & & $18(-71)$ & 63 & $96(+52)$ \\
Acetaldehyde & 16 & 16 & & $6(-73)$ & 22 & $33(+50)$ \\
Formaldehyde & 11 & 11 & & $4(-73)$ & 15 & $23(+53)$ \\
Formic acid & 1.6 & 1.6 & & $0.6(-73)$ & 2.2 & $3.3(+50)$ \\
Acetic acid & 0.3 & 0.3 & & $0.1(-75)$ & 0.4 & $0.7(+75)$ \\
TOTAL & $702(-3)$ & 725 & & $331(-64)$ & 912 & $1251(+37)$
\end{tabular}

a Percentage change in emissions relative to present-day is shown in parentheses.

[7] Present-day and preindustrial simulations are performed in static mode, using present-day climate forcing from CRU (Climate Research Unit, UK) with relative humidity corrected using ECMWF (European Centre for Medium-Range Weather Forecasts, UK) data. The vegetation distribution is prescribed with global maps based on the work by Loveland et al. [2000] which in turn was corrected for crops by Ramankutty and Foley [1999] and for anthropogenic grasses by Goldewijk [2001], to take into account the agriculture expansion between the preindustrial and present-day. The present-day orbital parameters (eccentricity: $0.06724^{\circ}$, perihelion: $102.04^{\circ}$, inclination: $23.446^{\circ}$ ) and climate conditions are applied for both the preindustrial and present-day simulations, and the atmospheric $\mathrm{CO}_{2}$ mixing ratio is set to $280 \mathrm{ppmv}$ and $350 \mathrm{ppmv}$ respectively.

[8] The LGM and future simulations are performed in dynamic mode, with climate conditions based on the present forcing corrected by the corresponding anomalies simulated with the LMDz (Laboratoire de Météorologie Dynamique) general circulation model [Harzallah and Sadourny, 1995] considering atmospheric $\mathrm{CO}_{2}$ mixing ratios of $180 \mathrm{ppmv}$ and 560 ppmv, respectively [Poutou et al., 2004]. For the LGM simulation, crops are removed and no initial condition for the vegetation distribution is considered: the simulation starts with bare soil and runs 500 years using the corrected LGM climate, orbital parameters (eccentricity: $0.018994^{\circ}$, perihelion: $114.42^{\circ}$, inclination: $22.949^{\circ}$ ) and atmospheric $\mathrm{CO}_{2}$ (180 ppmv) until equilibrium is reached. For the 2100 scenario, we focus on the impact of future climate and atmospheric $\mathrm{CO}_{2}$ on vegetation distribution and biogenic emissions. Thus, we keep the present-day crop distribution without accounting for any future land-use change. It seems likely that crop distribution and coverage will be significantly modified by 2100 . However, the future crop distribution is highly uncertain and many factors, such as crop yield improvement or evolution of agricultural practices would have to be considered, which are beyond the scope of our study. The future simulation starts from the present-day vegetation distribution and runs for about 500 years with present-day orbital parameters, future climate and atmospheric $\mathrm{CO}_{2}$ level of 560 ppmv until equilibrium is reached.

[9] To avoid biases in the calculation of emissions change that may arise from the systematic errors of the Dynamic Global Vegetation Model (i.e. too many trees compared to grasses), we have performed one additional simulation for the present with computed dynamic vegetation (Table 1).

\section{Results}

[10] The total annual mean LAI simulated by ORCHIDEE for the four scenarios is depicted in Figure 1. The total LAI is calculated as the sum over the individual LAI for each PFT weighted by the grid box fraction covered by the corresponding PFT.

[11] At the LGM, the annual mean LAI is very small due to a shorter growing season. Nevertheless, at peak growth, the LAI goes up to $5 \mathrm{~m}^{2} / \mathrm{m}^{2}$ in a few regions (Europe, North America). The PFT distribution simulated by ORCHIDEE (not shown) indicates a strong expansion of grasslands, in particular the $\mathrm{C}_{3}$-type. This large grasses and tundra expansion at the LGM has also been obtained by Levis et al. [1999] using the IBIS global vegetation model. The annual mean LAI reaches $1-3 \mathrm{~m}^{2} / \mathrm{m}^{2}$ in the eastern USA, South America, Indonesia and Central Africa, and $3-4 \mathrm{~m}^{2} / \mathrm{m}^{2}$ in northern Europe, corresponding to regions where trees are the dominant PFTs.

[12] During the preindustrial era, the annual mean LAI ranges from 1 to $5 \mathrm{~m}^{2} / \mathrm{m}^{2}$ over North America, Europe and Eurasia and up to $6 \mathrm{~m}^{2} / \mathrm{m}^{2}$ in the tropical regions of Amazonia, Central Africa and Indonesia. The LAI evolution between 1850 and present-day reflects the increased atmospheric $\mathrm{CO}_{2}$, and also the cropland expansion, especially in regions of the Northern Hemisphere, affecting first grass coverage [Ramankutty and Foley, 1999; Goldewijk, 2001], but also temperate trees (USA, Western and Central Europe). In central and eastern North America, the conversion of grasses into crops results in a LAI increase of 1 to $1.5 \mathrm{~m}^{2} / \mathrm{m}^{2}$. In South America and Indonesia, where trees

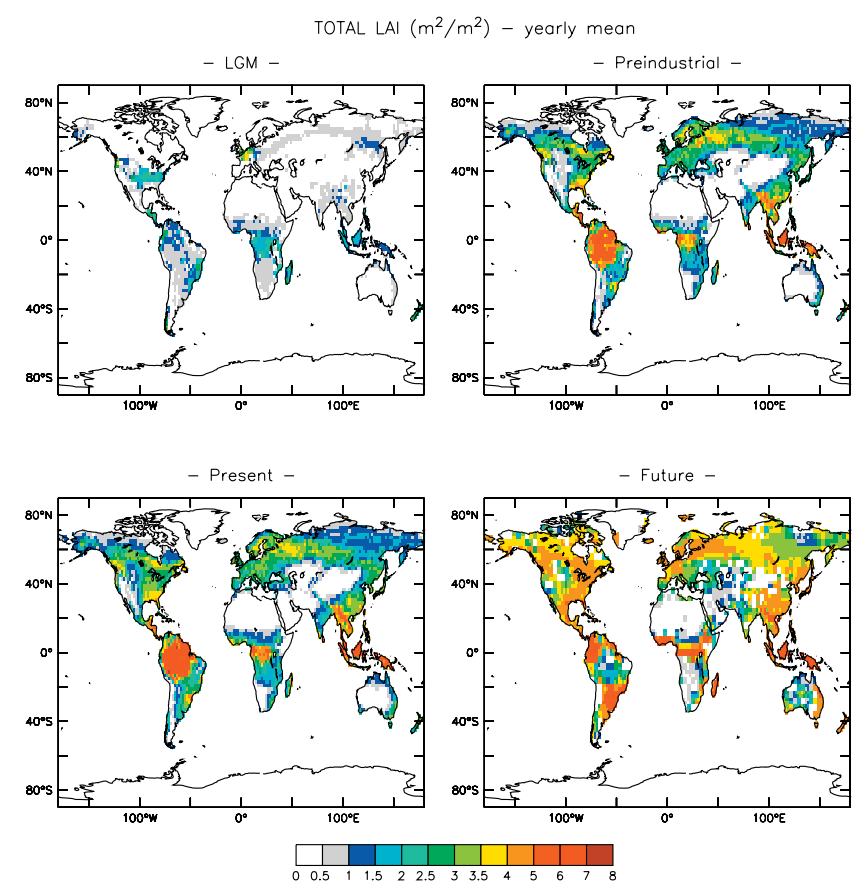

Figure 1. Calculated annual mean total leaf area index $\left(\mathrm{m}^{2} / \mathrm{m}^{2}\right)$ for the LGM, preindustrial, present-day (fixed vegetation) and future scenarios. 


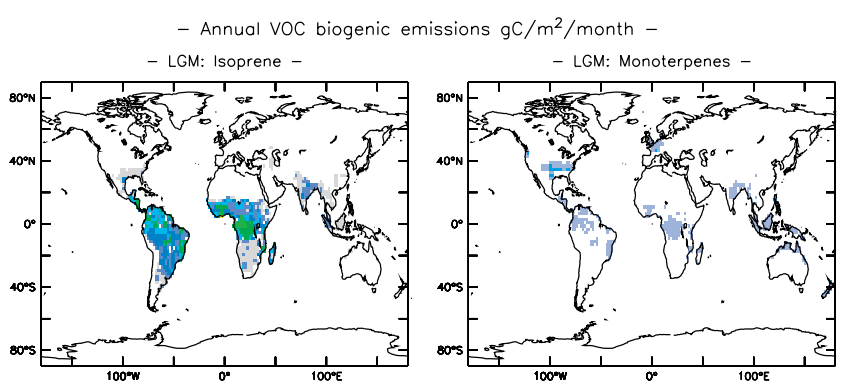

- Present: Isoprene -

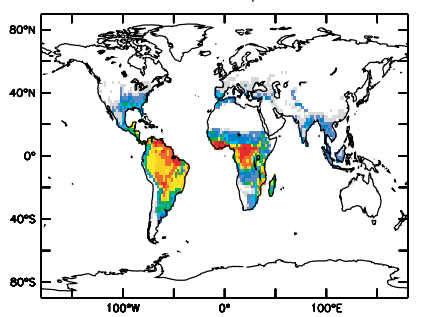

- Future: Isoprene -
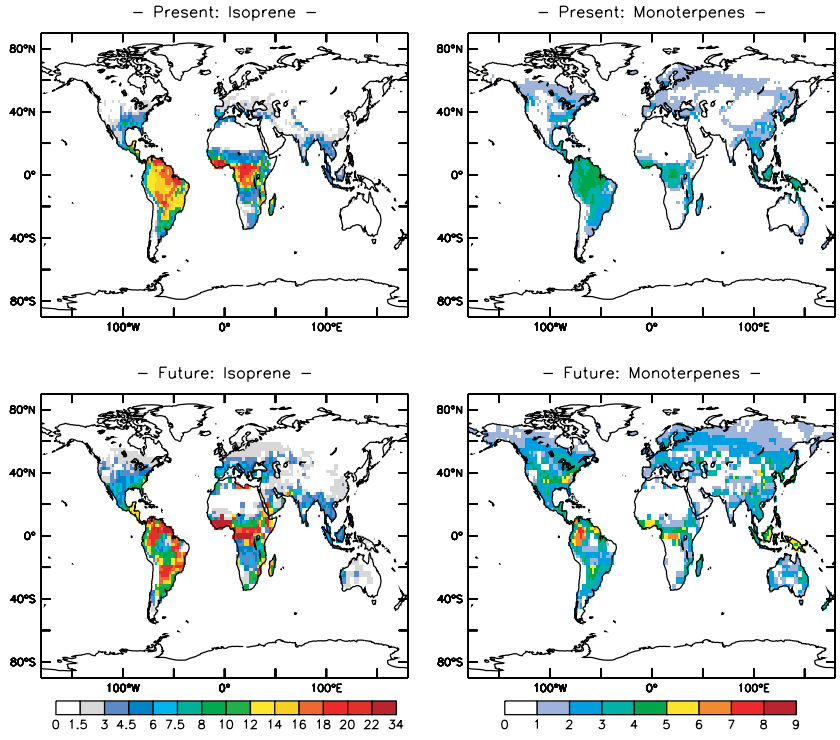

Figure 2. Distribution of annual biogenic emissions (gC/m $/ \mathrm{m}^{2} / \mathrm{month}$ ) for the LGM (first line), present-day (second line) and future (third line) for (left) isoprene and (right) monoterpenes.

have not been significantly affected by land-use change, the vegetation benefits from the atmospheric $\mathrm{CO}_{2}$ increase and the LAI varies from $5 \mathrm{~m}^{2} / \mathrm{m}^{2}$ at the preindustrial to $7 \mathrm{~m}^{2} / \mathrm{m}^{2}$ for present-day. The differences between the present-day prescribed and computed (not shown) vegetation maps reflect the DGVM tendency to grow too many trees compared to grasses, leading to a LAI increase by $1-1.5 \mathrm{~m}^{2} / \mathrm{m}^{2}$ in north-east America or Europe, and by $2-3 \mathrm{~m}^{2} / \mathrm{m}^{2}$ in southern tropical regions of America and Africa, in dynamic mode.

[13] In the future scenario, a strong LAI increase is calculated over large areas of the Northern Hemisphere where the total annual mean LAI is $4-5 \mathrm{~m}^{2} / \mathrm{m}^{2}$. This results from a large expansion of temperate and boreal forests all over northern America, Europe and Russia. In regions where annual precipitation decreases significantly in the future (not shown), such as South America and Central Africa, a strong reduction of tropical tree coverage is predicted by the model, leading to a major LAI decrease. Based on the TRIFFID global vegetation model, Cox et al. [2000] also found a loss of forest in South America, resulting from a drying and warming of Amazonia.

[14] The global vegetation change calculated by the model from the LGM to 2100 has a strong impact on biogenic VOC emissions, as presented in Table 1. For present-day conditions, the calculated global source is
$402 \mathrm{TgC} / \mathrm{yr}$ for isoprene, $131 \mathrm{TgC} / \mathrm{yr}$ for monoterpenes and $116 \mathrm{TgC} / \mathrm{yr}$ for methanol, and totals $75.9 \mathrm{TgC} / \mathrm{yr}$ for other VOCs (Table 1, static mode). Preindustrial global biogenic emissions total $702 \mathrm{TgC} / \mathrm{yr}$ and are close to present-day values, except for methanol for which a $22 \%$ decrease is predicted. Based on a preindustrial static simulation using present-day atmospheric $\mathrm{CO}_{2}$, we estimate that the vegetation distribution change in 1850 s compared to $1990 \mathrm{~s}$, and especially the crops reduction, leads to an emission change reaching $+7 \%$ for isoprene and monoterpenes and $-14 \%$ for methanol, while the atmospheric $\mathrm{CO}_{2}$ reduction from 350 to $280 \mathrm{ppmv}$ leads to a $5 \%$ (isoprene) to $11 \%$ (monoterpenes) decrease in emissions. LGM and future VOC emissions need to be compared to the present simulation carried out with dynamic vegetation (Table 1). Emission changes at the LGM (compared to emissions for the present day calculated using the simulated vegetation distribution) are $-55 \%$ for isoprene $(226 \mathrm{TgC} / \mathrm{yr}),-79 \%$ for methanol (27 TgC/yr), and most of other VOCs show a 73\% decrease. In the future scenario, the emission increases, again compared to those for the present day calculated from the dynamic simulation, range from $27 \%$ for isoprene $(638 \mathrm{TgC} / \mathrm{yr})$, which is closed to the increase from $484 \mathrm{TgC} / \mathrm{yr}$ to $615 \mathrm{TgC} / \mathrm{yr}$ found by Sanderson et al. [2003], to $45 \%$ for methanol (192 TgC/yr) and 50\% for other VOCs.

[15] In order to assess the impact of ecosystem distribution change on global biogenic VOC emissions, we performed the LGM and future simulations in static mode, i.e. applying the same climate, orbital and $\mathrm{CO}_{2}$ conditions but fixing the vegetation to its present-day distribution. Comparing global emissions calculated in static mode at the LGM (330 TgC/yr for isoprene, $92 \mathrm{TgC} / \mathrm{yr}$ for monoterpenes and $66 \mathrm{TgC} / \mathrm{yr}$ for methanol) with 1990s global emissions (Table 1), we can conclude that the strong VOC emissions change compared to present-day is primarily linked to LGM climate, orbital and $\mathrm{CO}_{2}$ conditions, and the related change in the LAI, which contribute to more than $60 \%$ of the emissions decrease. In the future static simulation, global emissions (520 TgC/yr for isoprene, $189 \mathrm{TgC} / \mathrm{yr}$ for monoterpenes and $147 \mathrm{TgC} / \mathrm{yr}$ for methanol) are significantly lower than the future dynamic simulation estimates, showing the major contribution of ecosystems distribution change to biogenic VOC emission increases between the present day and 2100 , reaching $87 \%$ for isoprene, $85 \%$ for monoterpenes and $75 \%$ for methanol. In addition to that, it should also be noted that during the LGM, the continental shelves were larger owing to the lower sea levels, and these areas were also covered by vegetation that emitted VOCs. In our model, this leads to an additional emission of $35 \mathrm{TgC} / \mathrm{yr}$ for isoprene and $14 \mathrm{TgC} / \mathrm{yr}$ for monoterpenes.

[16] As illustrated in Figure 2, annual biogenic VOC emissions and their geographical distribution change significantly from the LGM to 2100 . For all cases, the tropics remain a high emission region. Isoprene emissions in the tropics increase from 3-12 $\mathrm{gC} / \mathrm{m}^{2} /$ month at the LGM to 5$22 \mathrm{gC} / \mathrm{m}^{2} /$ month in 1990 and up to $34 \mathrm{gC} / \mathrm{m}^{2} /$ month in 2100. Monoterpenes emissions in tropical regions are less than $2 \mathrm{gC} / \mathrm{m}^{2} /$ month at the LGM, reach $5 \mathrm{gC} / \mathrm{m}^{2} /$ month for the present and up to $9 \mathrm{gC} / \mathrm{m}^{2} /$ month in 2100 . A strong emission decrease, down to $5 \mathrm{gC} / \mathrm{m}^{2} /$ month for isoprene and $2 \mathrm{gC} / \mathrm{m}^{2} /$ month for monoterpenes, is calculated in 2100 over the Amazon region, in response to the recession of 
tropical trees and LAI decrease. VOC emissions are generally much lower in the Northern Hemisphere compared to tropical regions but increase significantly at northern midand high (VOCs other than isoprene only) latitudes between 1990 and 2100, as a consequence of a large temperate and boreal forests expansion.

\section{Conclusion}

[17] Based on an interactive global biogenic emission and dynamic vegetation model, we investigate the evolution of biogenic VOC emissions in four scenarios of climate, $\mathrm{CO}_{2}$ and vegetation distribution changes: the Last Glacial Maximum (21,000 years BP), the preindustrial (1850s), presentday (1990s), and the future (2100). Global biogenic VOC emissions total $331 \mathrm{TgC} / \mathrm{yr}$ at the LGM, $702 \mathrm{TgC} / \mathrm{yr}$ for the $1850 \mathrm{~s}, 725 \mathrm{TgC} / \mathrm{yr}$ for the $1990 \mathrm{~s}$ and $1251 \mathrm{TgC} / \mathrm{yr}$ for 2100. Static and dynamic-mode simulations at LGM and 2100 indicate that the strong biogenic VOC emissions decrease calculated for the LGM is linked to the cold and dry climate, low atmospheric $\mathrm{CO}_{2}$ level and orbital conditions, whereas the important increase predicted in the future is mostly due to the change in ecosystem distribution. Tropical regions remain a strong VOC source in the four scenarios but a significant decrease in emissions is simulated in 2100 for the Amazon region, owing to a decrease in both the coverage of tropical trees and LAI. A large expansion of temperate and boreal forests is simulated over northern midand high latitudes, leading to a strong biogenic emissions increase.

[18] The impact of climate change on ecosystem growth and distribution can vary significantly depending on the region, which emphasizes the importance of considering all parameters including climate, atmospheric $\mathrm{CO}_{2}$ and their impact on ecosystems while estimating biogenic VOC emissions. Nevertheless, there are still huge uncertainties about ecosystems adaptation and distribution under global change conditions. We must underline that the biogenic emissions we calculate for the future are based on a vegetation distribution in equilibrium with future climate conditions, which will not be the case in 2100. As the Earth's climate will progressively change in the following decades, the vegetation distribution in 2100 could be rather different from the one calculated in the present work, possibly with a more moderate expansion of boreal forests. Moreover, even if tropical forest recession in response to climate change is less pronounced than that simulated by ORCHIDEE, vegetation could also suffer from human activities and development, particularly deforestation. Indeed, based on economic activity and demographic growth projections performed with the IMAGE 2 model, Alcamo et al. [1996] suggested that in the next 50 years, land-cover change will occur predominantly in the tropics. Ecosystems will thus have not only to adapt to climate change but also to suffer from the direct anthropogenic pressure of land-use, with major potential consequences on VOC emissions, tropospheric chemistry and, more generally, on biosphere-atmosphere interactions.

[19] The future scenario results suggest a large biogenic VOC emissions increase in the Northern Hemisphere, notably over regions affected by high anthropogenic $\mathrm{NO}_{\mathrm{x}}$ emissions, such as the eastern USA or Europe, which will favour photochemical production of ozone. Global simulations with the LMDz-INCA chemistry-climate model (D. A. Hauglustaine et al., Future tropospheric ozone simulated with a climate-chemistry-biosphere model, submitted to Geophysical Research Letters, 2005) are currently underway to assess this potentially important feature.

[20] Acknowledgments. Computer time was provided by the C.C.R.T under project p24. This work was partly funded by the European projects RETRO (EVK2-CT-2002-00170) and ENSEMBLES (GOCE-CT2003-505539). Gerd Folberth acknowledges support provided by the Canadian Centre for Climate Modelling and Analysis, Meteorological Service of Canada.

\section{References}

Alcamo, J., G. J. J. Kreileman, J. C. Bollen, G. J. van den Born, R. Gerlagh, M. Krol, A. M. C. Toet, and H. J. M. deVries (1996), Baseline scenarios of global environmental change, Global Environ. Change, 6, 261-303. Constable, J. V. H., A. B. Guenther, D. S. Schimel, and R. K. Monson (1999), Modelling changes in VOC emission in response to climate change in the continental United States, Global Change Biol., 5, 791806 .

Cox, P. M., R. A. Betts, C. D. Jones, S. A. Spall, and I. J. Totterdell (2000), Acceleration of global warming due to carbon cycle feedbacks in a coupled climate model, Nature, 408, 184-187.

Goldewijk, K. K. (2001), Estimating global land use change over the past 300 years: The HYDE database, Global Biogeochem. Cycles, 15, 417433.

Guenther, A., et al. (1995), A global model of natural volatile organic compound emissions, J. Geophys. Res., 100, 8873-8892.

Harzallah, A., and R. Sadourny (1995), Internal versus SST-forced atmospheric variability as simulated by atmospheric general circulation model, J. Clim., 8, 474-495.

Krinner, G., N. Viovy, N. de Noblet-Ducoudré, J. Ogée, J. Polcher, P. Friedlingstein, P. Ciais, S. Sitch, and I. C. Prentice (2005), A dynamic global vegetation model for studies of the coupled atmosphere-biosphere system, Global Biogeochem. Cycles, 19, GB1015, doi:10.1029/ $2003 \mathrm{~GB} 002199$

Lathière, J., D. A. Hauglustaine, A. Friend, N. De Noblet-Ducoudré, N. Viovy, and G. Folberth (2005), Impact of climate variability and land use change on global biogenic volatile organic compounds emissions, Atmos. Chem. Phys., in press.

Levis, S., J. A. Foley, and D. Pollard (1999), $\mathrm{CO}_{2}$, climate, and vegetation feedbacks at the Last Glacial Maximum, J. Geophys. Res., 104, 31,19131,198 .

Loveland, T. R., B. C. Reed, J. F. Brown, D. O. Ohlen, Z. Zhu, L. Yang, and J. W. Merchant (2000), Development of a global land cover characteristics database and IGBP DISCover from $1 \mathrm{~km}$ AVHRR data, Int. J. Remote. Sens., 21, 1303-1330.

Poutou, E., G. Krinner, C. Genthon, and N. de Noblet-Ducoudre (2004), Role of soil freezing in future boreal climate change, Clim. Dyn., 23, $621-639$.

Ramankutty, N., and J. A. Foley (1999), Estimating historical changes in global land cover: Croplands from 1700 to 1992, Global Biogeochem. Cycles, 13, 997-1027.

Sanderson, M. G., C. D. Jones, W. J. Collins, C. E. Johnson, and R. G. Derwent (2003), Effect of Climate Change on Isoprene Emissions and Surface Ozone Levels, Geophys. Res. Lett., 30(18), 1936, doi:10.1029/ 2003GL017642.

Schade, G. W., and A. H. Goldstein (2001), Fluxes of oxygenated volatile organic compounds from a ponderosa pine plantation, J. Geophys. Res., 106, 3111-3123.

Thunis, P., and C. Cuvelier (2000), Impact of biogenic emissions on ozone formation in the Mediterreanean area-A BEMA modelling study, Atmos. Environ., 34, 467-481.

Tsigaridis, K., and M. Kanakidou (2003), Global modelling of secondary organic aerosol in the troposphere: A sensitivity analysis, Atmos. Chem. Phys., 3, 1849-1869.

G. A. Folberth, School of Earth and Ocean Sciences (SEOS), University of Victoria, Victoria, BC., Canada V8W 2 Y2.

D. A. Hauglustaine, J. Lathière, and N. De Noblet-Ducoudré, Laboratoire des Sciences du Climat et de l'Environnement (LSCE), F-91191 Gif-surYvette, France. (juliette.lathiere@cea.fr; hauglustaine@cea.fr)

G. Krinner, Laboratoire de Glaciologie et Géophysique de l'Environnement (LGGE), F-38402 Saint Martin d'Heres, France. 